\title{
Nutrient Composition of Pastures in Kayunga District, Uganda: A Preliminary Investigation with Implications for Seasonal Supplementation in Grazing Ruminants
}

\author{
Ellen S. Dierenfeld ${ }^{1,2}$, Ben Lukuyu ${ }^{3}$, David Nyagaka4 \\ ${ }^{1}$ Novus International, Inc., St. Charles, USA \\ ${ }^{2}$ Ellen S. Dierenfeld LLC (Current), St. Louis, USA \\ ${ }^{3}$ International Livestock Research Institute, Nairobi, Kenya \\ ${ }^{4}$ Novus International, Inc., Nairobi, Kenya \\ Email: edierenfeld@aol.com
}

Received 16 January 2014; revised 19 February 2014; accepted 7 March 2014

Copyright (C) 2014 by authors and Scientific Research Publishing Inc.

This work is licensed under the Creative Commons Attribution International License (CC BY). http://creativecommons.org/licenses/by/4.0/

\section{Open Access}

\section{Abstract}

Proximate nutrient composition (crude protein, non-fiber carbohydrates, crude fiber, and ash), fiber fractions (neutral detergent fiber (NDF), acid detergent fiber (ADF), lignin), and both macro(calcium (Ca), phosphorus (P), magnesium (Mg), potassium (K), sodium (Na), and sulfur (S)) and trace (copper (Cu), iron (Fe), manganese (Mn), molybdenum (Mo), and zinc ( $\mathrm{Zn})$ ) mineral profiles were quantified in mixed pasture samples collected during the wet $(n=8)$ and dry $(n=15)$ seasons in north central Uganda. Metabolizable and Net Energy values for dairy production were estimated based on standard calculations, and samples were compared seasonally. Crude fat $(p=$ $0.05)$ and lignin $(p=0.01)$ values were lower in the dry season compared with the wet season, linked with reduced plant growth. Crude protein (13.0\% of dry matter (DM)), fiber fractions, and calculated energy content did not vary seasonally in this data set, and reflected chemical components of a grass-dominated system that appeared energetically limiting for production livestock. Mineral constituents varied more dramatically by season, with $\mathrm{Ca}, \mathrm{Mg}, \mathrm{Cu}$, and $\mathrm{Mn}$ lower (all < 0.05$)$ and $\mathrm{K}$ higher in the dry season. Sodium was deficient in these pastures, whereas $\mathrm{Ca}, \mathrm{P}, \mathrm{Mg}, \mathrm{S}, \mathrm{Cu}$, and $\mathrm{Zn}$ concentrations may have been only marginally sufficient, particularly to meet needs for lactation, dependent on season. These limited data suggest that a high-energy mineral supplement may prove beneficial in meeting nutritional and production needs of multiple grazing ruminant species in this region, particularly during dry seasons. 


\section{Keywords}

\section{Cattle; Forage; Minerals; Nutrition}

\section{Introduction}

Carrying capacity of rangelands utilized in the Ankole grazing system in Uganda has been previously modeled [1], and has been found to be highly dependent on rainfall patterns, thus subject to strong seasonality. Pasture nutrient resources (sampled in approximately 2-mo intervals corresponding to wet/dry seasons) -measured as either average dry matter production [1] or crude protein content [2] —were also highly variable; cattle body condition and productivity decline with the dry season and recover during wet seasons. Although animals can respond to lower available forage in the dry season behaviorally through selective feeding and browsing, pasture nonetheless provides primary nutrition year-round. Both quantity and quality characteristics must be considered in order to optimize nutritional strategies, including the need for supplementation. This study provides baseline information on proximal nutrient and mineral constituents of pastures utilized by grazing livestock during dry season compared to wet season in the Bbale district of central Uganda.

\section{Materials and Methods}

Pasture samples ( $\mathrm{n}=8$ wet season; $\mathrm{n}=15$ dry season) were randomly sampled from open rangelands grazed by Ankole cattle in Kayunga District, Bbale County, Uganda by hand-clipping all ground cover encircled in a $1 \mathrm{~m}^{2}$ open frame. Wet season samples were taken April/May 2011, whereas dry season samples were collected from the same locale in November/December 2010. Samples were weighed, air-dried in the field, and then oven-dried at $60^{\circ} \mathrm{C}$ in the Department of Animal Sciences, Makerere University, Kampala. Samples were ground through a $1 \mathrm{~mm}$ screen, and analyzed using standard laboratory methods

(http://dairyone.com/wp-content/uploads/2014/02/Forage-Lab-Analytical-Procedures.pdf); minerals were analyzed on a Thermo ICAP 6300 Inductively Coupled Plasma(ICP) Radial Spectrometer (Thermo Fisher Scientific, Inc., Waltham, MA 02454, USA). Seasonal comparisons in nutrient content were evaluated using unpaired t-tests, with significance set at $\mathrm{P}<0.05$.

\section{Results and Discussion}

Proximate (crude protein, crude fat, non-fiber carbohydrates (NFC), ash), cell wall constituents (acid detergent fiber (ADF), neutral detergent fiber (NDF), lignin), energy estimates, and mineral concentrations in pasture samples are reported in Table 1, whereas dietary nutrient recommendation summary ranges for various livestock species are in Table 2. Higher nutrient densities in the reported ranges of Table 2 correspond to higher production stages (growth, late reproduction, lactation). Although mean crude protein did not differ seasonally between samples, percent soluble protein was higher $(\mathrm{P}=0.03)$ in samples collected from the dry vs. the wet season. Protein content measured in this study (with one exception) was similar to mean protein recorded in 10 major grasses (mixed) sampled in 4 regions of Uganda (12.2\% Acholilango area, 12.7\% Eastern region, 15.7\% BuganaBusoga Lake shore, 5.97\% Ankole zone; [3], reported by [4]. Nonetheless, crude protein in native pastures ( 13\% of dry matter (DM)) appeared adequate to meet basal requirements for all species, except perhaps at highest stages of production.

Overall fiber (NDF and ADF) concentrations did not vary seasonally in these samples, but the lignin content of samples collected in the dry season was lower than that of wet season samples, likely due to lower degree of maturity in pasture sampled during the dry season. Due to lower lignification as a proportion of plant cell walls (lignin/NDF or lignin/ADF), dry season pasture had a potentially higher fermentation value compared to wet season forages; this difference, however, was not seen in estimated energy values of the samples. Sabiiti and Mugerwa [4], using in vitro digestibility techniques, reported 3\% to $15 \%$ higher digestibility of wet vs. dry season forages (Panicum in pure stand or with 4 different legumes) in Uganda, with digestibility values ranging from $43 \%$ to $61 \%$. Certainly ruminant species with healthy rumen function should be able to utilize native pastures for energy production. The metabolizable energy concentrations in these forages $(1.7 \mathrm{MKcal} / \mathrm{kg})$, as well 
Table 1. Nutrient profile of mixed pasture samples from Kayunga District, Bbale County, Uganda collected 2010-11. All nutrients (except Dry Matter (DM) on a DM basis.

\begin{tabular}{|c|c|c|c|c|c|c|}
\hline \multirow[t]{2}{*}{ Nutrient } & \multirow[t]{2}{*}{ Unit } & \multirow{2}{*}{$\begin{array}{c}\text { Wet Season }(n=8) \\
\text { Mean }\end{array}$} & \multicolumn{3}{|c|}{ Dry Season $(n=15)$} & \multirow{2}{*}{$\begin{array}{c}\text { Seasonal Comparison } \\
\text { P value }\end{array}$} \\
\hline & & & SD & Mean & SD & \\
\hline Dry Matter & $\%$ & 90.76 & 0.45 & 89.70 & 1.9 & 0.03 \\
\hline Crude Protein & $\%$ & 12.80 & 3.49 & 13.15 & 7.4 & 0.44 \\
\hline Soluble Protein & $\%$ & 44.25 & 4.57 & 57.21 & 21.5 & 0.03 \\
\hline $\mathrm{ADF}$ & $\%$ & 38.70 & 4.40 & 34.31 & 12.3 & 0.09 \\
\hline NDF & $\%$ & 62.41 & 3.30 & 57.39 & 16.6 & 0.14 \\
\hline Lignin & $\%$ & 7.10 & 1.58 & 4.71 & 3.2 & 0.01 \\
\hline NFC & $\%$ & 7.33 & 3.55 & 8.64 & 3.6 & 0.22 \\
\hline Fat & $\%$ & 1.95 & 0.65 & 1.41 & 0.8 & 0.05 \\
\hline Ash & $\%$ & 11.43 & 2.04 & 17.69 & 18.3 & 0.11 \\
\hline Digestible Energy & Mcal/kg & 2.2 & 0.3 & 2.2 & 0.6 & 0.46 \\
\hline Metab Energy & Mcal/kg & 1.7 & 0.3 & 1.7 & 0.7 & 0.48 \\
\hline NE Lactation & $\mathrm{Mcal} / \mathrm{kg}$ & 0.9 & 0.2 & 0.9 & 0.4 & 0.49 \\
\hline NE Maintenance & $\mathrm{Mcal} / \mathrm{kg}$ & 0.9 & 0.2 & 0.9 & 0.5 & 0.45 \\
\hline NE Gain & Mcal/kg & 0.4 & 0.2 & 0.5 & 0.3 & 0.23 \\
\hline \multicolumn{7}{|l|}{ Minerals } \\
\hline $\mathrm{Ca}$ & $\%$ & 0.44 & 0.08 & 0.31 & 0.1 & $<0.01$ \\
\hline $\mathrm{P}$ & $\%$ & 0.23 & 0.07 & 0.34 & 0.5 & 0.18 \\
\hline $\mathrm{Mg}$ & $\%$ & 0.24 & 0.07 & 0.18 & 0.1 & 0.03 \\
\hline $\mathrm{K}$ & $\%$ & 1.60 & 0.42 & 2.29 & 1.3 & 0.04 \\
\hline $\mathrm{Na}$ & $\%$ & 0.01 & 0.01 & 0.02 & 0.1 & 0.19 \\
\hline $\mathrm{Fe}$ & ppm & 1068.88 & 790.19 & 814.53 & 843.5 & 0.24 \\
\hline $\mathrm{Zn}$ & ppm & 33.38 & 15.59 & 24.67 & 8.1 & 0.09 \\
\hline $\mathrm{Cu}$ & ppm & 9.63 & 2.00 & 6.00 & 2.4 & $<0.01$ \\
\hline Mn & ppm & 194.75 & 89.52 & 107.60 & 26.4 & 0.01 \\
\hline $\mathrm{S}$ & $\%$ & 0.17 & 0.06 & 0.18 & 0.1 & 0.34 \\
\hline Mo & ppm & 1.20 & 0.77 & 1.03 & 0.5 & 0.30 \\
\hline
\end{tabular}

ADF = acid detergent fiber; NDF = neutral detergent fiber; NFC = non-fiber carbohydrates; NE = net energy; Minerals: calcium (Ca), phosphorus (P), magnesium $(\mathrm{Mg})$, potassium $(\mathrm{K})$, sodium $(\mathrm{Na})$, iron $(\mathrm{Fe})$, zinc $(\mathrm{Zn})$, copper $(\mathrm{Cu})$, manganese $(\mathrm{Mn})$, sulfur (S), molybdenum (Mo).

as net energy (NE) lactation values ( $0.9 \mathrm{Mcal} / \mathrm{kg})$, however, suggest that energy may be a limiting nutrient in native pastures.

Total ash was numerically, but not statistically, higher in dry season compared to wet season samples, probably due to a greater proportion of soil contamination. Of the macrominerals analyzed, Ca and Mg were higher in wet season samples compared to dry season; the opposite was seen with $\mathrm{K}$ (the latter observation suggesting a less mature, perhaps slower growth stage of plant). Trace elements differed seasonally for $\mathrm{Cu}$ and $\mathrm{Mn}$, with wet season samples containing higher concentrations of these nutrients. As with most forages, all pastures sampled were grossly deficient in sodium relative to the dietary needs of ruminants, highlighting the essentially of providing a salt lick for grazing animals. Relative to animal requirements, both Ca and P needs, particularly of lactating cows (either dairy or beef) could be limiting in native pastures, depending upon the season and bioavailability (form) of macrominerals in the forages. Similarly, $\mathrm{Mg}$ and $\mathrm{S}$ supplied by pastures may prove marginal for dairy cows (and goats) in heavy lactation. Fe and Mn were found in relative excess, whereas $\mathrm{Cu}$ appears to be a limiting trace mineral across species and physiologic stages. It is also possible that high dietary Fe levels may limit or interfere with other mineral metabolism, most notably $\mathrm{Cu}$, as has been previously suggested [5]. Zn nutrition may be marginal, depending upon species, season, and stage of production-in general, Zn needs of lactating dairy cows were not met by native pastures in this study. Selenium (Se) and iodine (I) were not measured in these samples, but are known to be limiting in many regions of Sub-Saharan Africa [6]; livestock status should be evaluated to determine the need for supplementation in this region. 
Table 2. Target dietary nutrient concentrations for various grazing ruminants (DM basis). Ranges indicate varying levels associated with different stages of production.

\begin{tabular}{|c|c|c|c|c|c|}
\hline Nutrient & Unit & Lactating Cow Reqt [7] & Beef Reqt [8] & Sheep Reqt [9] & Goat Reqt [9] \\
\hline Crude Protein & $\%$ & $9.2-15.1$ & $7.4-16.6$ & $6.2-30$ & \\
\hline $\mathrm{ADF}$ & $\%$ & $17-21$ & & & \\
\hline NDF & $\%$ & $25-33$ & $20-57$ & $8.9-72.4$ & \\
\hline NFC & $\%$ & $36-44$ & & & \\
\hline Metab Energy & Mcal/kg & & $1.84-2.58$ & $1.63-3.17$ & 2.39 \\
\hline NE Lactation & $\mathrm{Mcal} / \mathrm{kg}$ & $1.37-1.8^{+}$ & & & \\
\hline NE Maintenance & $\mathrm{Mcal} / \mathrm{kg}$ & & $1-2.29$ & & \\
\hline NE Gain & $\mathrm{Mcal} / \mathrm{kg}$ & & $0.45-1.59$ & & \\
\hline \multicolumn{6}{|l|}{ Minerals } \\
\hline $\mathrm{Ca}$ & $\%$ & $0.3-0.48$ & $0.14-0.71$ & & \\
\hline $\mathrm{P}$ & $\%$ & $0.33-0.44$ & $0.13-0.29$ & & \\
\hline $\mathrm{Mg}$ & $\%$ & $0.18-0.29$ & $0.1-0.2$ & $0.12-0.18$ & \\
\hline $\mathrm{K}$ & $\%$ & $1.0-1.2$ & $0.6-0.7$ & & $0.5-0.8$ \\
\hline $\mathrm{Na}$ & $\%$ & 0.2 & $0.06-0.1$ & & 1.7 \\
\hline $\mathrm{Fe}$ & ppm & $12-22$ & 50 & 30 & $35-95$ \\
\hline $\mathrm{Zn}$ & ppm & $43-73$ & 30 & $20-51$ & $20-80$ \\
\hline $\mathrm{Cu}$ & ppm & $9-16$ & 10 & $7-11$ & $15-25$ \\
\hline $\mathrm{Mn}$ & ppm & $12-21$ & $20-40$ & $10-25$ & $20-120$ \\
\hline $\mathrm{S}$ & $\%$ & 0.2 & 0.15 & 0.18 & $0.16-0.36$ \\
\hline Mo & ppm & & & 0.5 & $0.1-1$ \\
\hline Se & ppm & & 0.1 & 0.3 & 0.3 \\
\hline I & ppm & 0.3 & 0.5 & $0.5-0.8$ & $0.5-0.8$ \\
\hline
\end{tabular}

$\mathrm{ADF}=$ acid detergent fiber; $\mathrm{NDF}=$ neutral detergent fiber; NFC = non-fiber carbohydrates; NE = net energy; Minerals: calcium (Ca), phosphorus (P), magnesium (Mg), potassium (K), sodium (Na), iron (Fe), zinc (Zn), copper (Cu), manganese (Mn), sulfur (S), molybdenum (Mo), selenium (Se), iodine (I).

\section{Conclusion}

Based on this limited sample, a high energy supplement with targeted minerals (both macro and trace) may improve overall animal nutrition, health, and productivity of grazing ruminant livestock in this region of Uganda, particularly during the dry season(s). A molasses-based block with added $\mathrm{Ca}, \mathrm{P}, \mathrm{Mg}, \mathrm{S}, \mathrm{Cu}$ and Zn-and possibly I and Se-may prove beneficial across multiple species.

\section{References}

[1] Mulindwa, H., Galukande, E., Wurzinger, M., OkeyoMwai, A. and Sölkner, J. (2009) Modelling of Long Term Pasture Production and Estimation of Carrying Capacity of Ankole Pastoral Production System in South Western Uganda. Livestock Research for Rural Development, 21, Article \#151. http://www.lrrd.org/lrrd21/9/muli21151.htm

[2] Okello, S., Sabiiti, E.N., and Schwartz, H.J. (2005) Factors Affecting in sacco Dietary Degradation by Ankole Cattle Grazing Natural Range Pastures in Uganda. African Journal of Range \& Forage Science, 22, 157-165. http://dx.doi.org/10.2989/10220110509485875

[3] Bredon, R.M. and Horell, C.R. (1961) The Chemical Composition and Nutritive Value of Some Grasses in Uganda. 1 General Pattern of Behaviour of Grasses. Nature, 194, 702-703. http://dx.doi.org/10.1038/194702a0

[4] Sabiiti, E.N. and Mugerwa, J.S. (1988) Forage Research and Development for Livestock Production in Uganda. In: PANESA/ARNAB (Pastures Network for Eastern and Southern Africa/African Research Network for Agricultural By-Products), Ed., Utilization of Research Results on Forage and Agricultural By-Product Materials as Animal Feed Resources in Africa, Proceedings of the First Joint Workshop, Lilongwe, 5-9 December 1988, PANESA/ARNAB, Addis Ababa, 833p. http://www.fao.org/wairdocs/ILRI/x5536E/x5536e0d.htm

[5] Dermauw, V., Yisehak, K., Belay, D., Van Hecke, T., Du Laing, G., Duchateau, L., and Janssens, G.P.J. (2013) Mineral Deficiency Status of Ranging Zebu (Bos indicus) Cattle around the Gilgel Gibe Catchment, Ethiopia. Tropical Ani- 
mal Health and Production, 45, 1139-1147. http://dx.doi.org/10.1007/s11250-012-0337-4

[6] Schillhorn van Veen, T.W. and Loeffler, I.K. (1990) Mineral Deficiency in Ruminants in Sub-Saharan Africa: A Review. Tropical Animal Health and Production, 22, 197-205. http://dx.doi.org/10.1007/BF02241018

[7] National Research Council (2001) Nutrient Requirements of Dairy Cattle. 7th Revised Edition, The National Academies Press, Washington DC.

[8] National Research Council (2000) Nutrient Requirements of Beef Cattle. 7th Revised Edition, The National Academies Press, Washington DC.

[9] National Research Council (2007) Nutrient Requirements of Small Ruminants: Sheep, Goats, Cervids, and New World Camelids. The National Academies Press, Washington DC. 